\title{
Legible and Thus Legitimate? Reading and Blurring Gender in China, Today and Yesterday
}

Coraline Jortay, Jennifer Bond and Chang Liu

\section{(2) OpenEdition}

\section{Journals}

Electronic version

URL: https://journals.openedition.org/chinaperspectives/10257

DOI: 10.4000/chinaperspectives. 10257

ISSN: 1996-4617

\section{Publisher}

Centre d'étude français sur la Chine contemporaine

Printed version

Date of publication: 1 September 2020

Number of pages: 5-8

ISSN: 2070-3449

\section{Electronic reference}

Coraline Jortay, Jennifer Bond and Chang Liu, "Legible and Thus Legitimate? Reading and Blurring Gender in China, Today and Yesterday", China Perspectives [Online], 2020-3 | 2020, Online since 01 September 2020, connection on 10 December 2021. URL: http://journals.openedition.org/ chinaperspectives/10257 ; DOI: https://doi.org/10.4000/chinaperspectives.10257 


\title{
Legible and Thus Legitimate? Reading and Blurring Gender in China, Today and Yesterday
}

\author{
CORALINE JORTAY, JENNIFER BOND, AND CHANG LIU
}

$\mathrm{n}$ her keynote address to the conference from which this special issue of China Perspectives has emerged, Prof. Gail Hershatter spoke of gender and "blindspotting": how practices of looking and bringing something into focus may cause other aspects to simultaneously fade out (Hershatter 2019). This idea builds on her previous work conceptualising gender as a "kind of lens that allows one to zoom in and out," an anchoring foothold that is "multi-scalar rather than scalable" (Hershatter 2012: 889, 891), allowing us to tease out seams and fractures in the historical terrain from the individual level to the state. Taking these erasures and reframings as a starting point, this special issue seeks to examine what is focused, defocused, or blurred when gender is used as the prism to examine Chinese society and cultural practices, and how - through gender - legibility and legitimacy become articulated in historically-situated social practices. Drawing on Foucault's and Fanon's relations of power and politics of looking, feminist theorist bell hooks impels us to recognise that "There is power in looking," (2003: 94) and that "subordinates in relations of power learn experientially that there is a critical gaze, one that 'looks' to document, one that is oppositional (...) - one learns to look a certain way in order to resist" (ibid.: 95). After all, looking away is political, too - as writer Claire-Louise Bennett would have it: "Even looking away was calculated. Even looking away was looking" (Bennett 2016: 177).

The wealth of scholarship now published on gender in China in areas as varied as labour practices, state and nationhood, marriage, family, and sexuality, as surveyed by Gail Hershatter (2007) as well as Robin Yates and Danni Cai (2018), testifies to the fact that a gendered lens has become pivotal to our understanding of modern and contemporary China. Scholarly attention in the field has historically emphasised women's studies, including China Perspectives 2012/4 edited by Isabelle Attané and its remarkable attention to women in China's demographic and economic transition. Building on this, our volume shifts the focus towards the immensely varied spectrum of expressions of Chinese femininities and masculinities, reflecting newer trends inaugurated by Susan Brownell and Jeffrey N. Wasserstrom (2002). Examining a wide range of marketable media involving reading and gazes (print, discursive and physical (self-)representations, posters, and screens: mobile apps, display videos, films), the contributions undertake a critical exploration of masculinities, decentred from a supposed universal experience. Scrutinising how social and cultural constructions of "legitimate" masculinities and femininities have been historically operative at the expense of other gendered identities, the following four articles expand into the realm of visuality what Amy Dooling has explored in modern literature.
She remarked that "narrative never simply reflects the hierarchical relations of power between men and women in society, but that it actively enables and authorises those relations by providing the emotional, ethical, cognitive, and imaginary structures that induce individuals to accept and identify with their 'proper' gender assignments" (Dooling 2005: 16). The process of interrogating our "blindspots" in the construction of legitimacy through legibility allows us, then, to expand the boundaries of what Judith Butler calls the "terms of intelligibility": cultural norms by which people are defined and made recognisable (1990: 183). Simply put, this special issue interrogates how "reading bodies" - as bodies who read and are read, gaze and are gazed at - are constructed as legitimate as far as they are legible, and as legible as far as they are legitimate. Whether the issue is to "read the room" (in Aurélia Ishitsuka's article in this issue) or to "read between the lines" (in Geng Yushu's article in this issue) is a discipline-related matter, but the power dynamics remain largely similar.

All four contributions foreground a management of desires, of sexualities, and ultimately of gendered identities through a regulation of "looking" and "being looked at": the banned obscene books (studied by Geng Yushu in this issue), the well-groomed Chinese gentlemen reining in libidinal energy towards respectability (studied by Derek Hird), the marketability of Han Han's 韓寒 ruggedly adventurous masculinity (studied by Pamela Hunt), or the hierarchies of desirable and undesirable bodies in coworking spaces (studied by Aurélia Ishitsuka). This careful management, of course, hints at the importance of market forces in shaping gendered relations of power, whether they are to be found in the Republican-era book market, the consumption of overseas higher education, Han Han's own commercial venture, or the transnational capitalism of emerging office spaces. Through a variety of gazes, bodies are read in turn as acceptable, desirable, properly Confucian, fashionable, or assigned several of these labels at once. They are in tension, legitimised and de-legitimised as they are being read. Class is also central to the analysis, as all articles point to how Chinese elites selectively drew upon transnationally circulating images of gender and sexuality in the construction of "moral" or "desirable" gendered identities. Another lens central to this analysis is race, for which we must foreground the pathbreaking work of Kimberlé Crenshaw on intersectionality (1989). Beyond an early focus on how race and gender intersect to deepen the marginalisation of African American women in the United States, Crenshaw's analytical tool has broadened to encompass the intersections of a wide variety of identity markers such as sexual orientation, social class, and disability. Paying attention to the entanglement of these identity markers 
is essential to understanding the social hierarchies of power that emerge in a variety of cultural contexts. The articles in this issue of China Perspectives highlight the centrality of race, as it is made legible - or even, illegible - in the construction of "Chinese" gendered identities. Its enduring importance is revealed in instances as varied as smoothed-out visions of Han Chinese travelling towards Western China unencumbered by the question of ethnic minorities, questions of Han-ness on the global stage, or the multiple ethnicities coexisting in Shanghai coworking spaces. If, following Hershatter, a gendered lens should be applied as a versatile tool for tackling unfamiliar historical terrain, then the issues raised by Black feminists can help us interrogate possible "blindspots": areas we cannot see because of our current position. Only when issues are put under the microscope of intersectional analysis can we achieve a greater clarity of vision. Together, the lenses of gender, race, and class equip us with an adjustable focal length, lest we let fade out more aspects than we bring into focus.

Purposely letting "inconvenient" views of gender fade out was certainly the goal of censors in Geng Yushu's article "What is Obscenity? Morality and Modernity in 1920s China." Examining lists of banned obscene books from 1922 to the early 1930s, including Ming-Qing fiction and Zhang Jingsheng's Sex Histories, Geng asks how and why certain texts became classified as "obscene." Apart from exploring the ambiguous legal definition of obscenity, the paper shows how male intellectuals and the popular press contributed to defining the boundaries between yinshu (obscene books 滔書) and legitimate publications. Male intellectuals in Republican China differentiated Dream of the Red Chamber from yinshu because it was based on qing 情, defined as love, affection, sentiment, and human nature, and thus a noble quality. Their arguments about qing provided a radical foundation for new culturalists to go against the Confucian social order. The popular press, however, presented a gender-differentiated perception of qing: while for men it conferred nobility, for women over-indulgence in qing could be dangerous and even lead to death. These concerns about qing not only reveal the resilience of Confucian order, but also indicate that "for both May Fourth intellectuals and urban masses, enlightenment and modernity had to be moral." To cross the line between yin and qing, intellectuals also adopted xing 性 to grant a "scientific" interpretation of qing. By probing into concepts of yin, xing, and qing in the 1920s, Geng highlights "the underlying cultural and intellectual currents supporting this negotiation of the boundaries of decency, an important facet of Chinese modernity that awaits further exploration."

The importance of constructing the boundaries of "respectable" or moral sexuality in the process of defining modern Chinese gendered identities is also probed in Derek Hird's article. In order to resolve the ambivalences of Chinese masculinity, which Hird traces back to the unequal and emasculating power dynamics of the mid-nineteenth century and which have resurfaced today under new transnational capitalist forces, Hird argues that highly educated overseas Chinese men have sought refuge in the notion of the "Confucian sublime." Drawing on news articles, TV dramas, literature, and interviews with overseas Chinese men, Hird argues that the Confucian sublime is "the seductive idea of an idealised Confucian political order, ruled over by virtuous men." The political discourse and various kinds of cultural representation in 2010s China have re-centred Confucian rituals on filial piety, the patrilineal family, as well as the social hierarchy that subordinates the individual to the family and the family to the state. Self-narratives of male middle-class Chinese professionals show how they selectively borrow from their British counterparts to train their gentlemanly manners. However, more importantly, they refer to Confucianism and Taoism to cultivate their minds. In this way, they translate the Confucian ideal gentleman, junzi $尹$ 子, across national boundaries to produce a global vision framed in the Confucian idea of tianxia 天下 (all under the heaven), which in turn is mobilised in political discourses to argue for China's position in a new global order.

Envisioning consumable and globally legible Chinese masculinities is also at the heart of Pamela Hunt's article. This is exemplified by what she terms the Han Han phenomenon, "the rapid rise to fame of this multi-hyphenate pop culture icon." While fans, commentators, and the audience usually portray Han as a defiant and masculine rebel who persistently challenges the cultural and political boundaries of mainstream Chinese society, Hunt shows that the celebration of masculinity on the move through Han's public image is nevertheless constrained by "global cultural influences, local traditions of manhood, and new market forces." Focusing on the recurring imagery of geographic mobility and road travelling in Han's commercials and his debut film The Continent (Houhui wuqi 後會無期), the paper traces the tropes that travelled through space and time in shaping the fashionable masculinity he portrays: the western cowboy, the local knight-errant and good fellow in popular novels of the Ming dynasty, as well as the scholar-

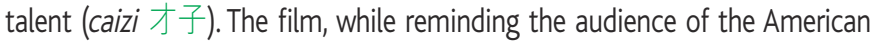
film Easy Rider in 1969, also echoes the Chinese male privilege of travelling based on the traditional segregation of gender roles, which positioned men as the masters of the outer realm (wai 外) while women were in charge of domestic affairs (nei 內). It is on the road, for example, that one protagonist redeemed his cultural attainment (wen 文), which built up to his career success when he finally returned home. Han's masculinity, Hunt argues, was however "constructed at the expense of women and non-hegemonic men." Moreover, the film is framed against images of imported cars, economically marginalised women, the prodigious construction of motorways, and other elements that provide grounding to a conception of masculinity within the context of the market economy of China's Reform era.

Global cultural influences and marketing imperatives in the making of modern Chinese gender identities are further revealed in Aurélia Ishitsuka's case study on "the Hub," an office space provider marketed as a "crossborder community" in cosmopolitan Shanghai. The paper examines the desirability of bodies in the co-working space for both Chinese and foreign professionals. Ishitsuka shows how bodies become legible through visual encounters, encompassing social interactions in physical and virtual spaces as well as their representation in promotional material. The expectation that paying members watch out for strangers marks the space as a "safe" community designed exclusively for a mobile global middle class, revealing the reproduction of a hierarchy between transnational and rural-urban migrants. Ironies abound: the space could not function without the migrant labour of security guards, cleaners, and delivery men. The controlled lettingin of "undesirable" bodies is further conducted as a purposeful management of desires: the sober uniforms of female cleaners render them invisible, nonsexualised beings. In the meantime, clientele from China, North America, Europe, and other parts of Asia pursue fit and self-controlled bodies through in-house sport facilities, dressing, and diet. As Ishitsuka's paper shows, the Hub draws borders to control entry to the space, but for the members it breaks down boundaries between work and play, professional and private, sex and business. The company not only promotes romantic stories of Asianwoman-meets-white-man in promotional videos, it also strategically brands its liberal values by evoking male homosexual encounters in its commercials. In sum, Ishitsuka offers an analysis of how the differentiation of two kinds of migrant bodies - one transnational, the other rural-urban - determines 
belonging in the coworking space whereas encounters between members are shaped by a racial and gender division of labour.

Boundaries, drawn and blurred, imposed and negotiated, are at the heart of all four papers. The "legitimate" and therefore "legible" identities that they create are constructed along gender, race, and class lines, but questions remain about their intersections: What would an "undesirable" white body look like in the transnational environment of the Hub? How far is Han ethnicity central to the construction of Han Han's mobile manhood? And how are other minority ethnicities erased while the film leads towards Western China? How might a working-class Chinese man, without the benefits of a Western degree, construct a masculine identity within a foreign environment that has historically valorised the rugged masculinity of the working class, but has also radicalised and effeminised Asian immigrants? How far did race alter the definition of what was considered "obscene" literature in the Republican period - and were upper-class women more susceptible to being overly stimulated by qing than their working-class counterparts?

What comes through strongly is how legible bodies are made visible through their marketability and consumption. The market plays a strong role in Han Han's performance of his go-getting masculinity, packaged for an aspirational globe-trotting middle class. The consumption of an overseas education is also essential to the ways in which the "enlightened" Confucian gentlemen construct their moral identity in contrast to the "other" modes of masculinity performed in the West. The market for obscene books drives consumption, even as state forces try to circumscribe the limits of their representation. And in today's Shanghai, not only are elite transnational bodies marketed and made visible in the promotional material of the Hub, its members consume this elite lifestyle and participate actively in producing such images through regulating their own bodies and training their own gaze to consume what are identified as "desirable" bodies in these spaces. Gendered identities in all four articles are produced through self-conscious acts of consumption, with the market circumscribing and legitimating what gendered identities become legible. One result of these dynamics is a sense of dislocation. The gendered identities that emerge from all four papers share a sense of isolation, a hard-to-shake loneliness that comes out of a bodily mobility, transnational experience, and movement of ideas across boundaries. They are left with a feeling of homelessness, of unbelonging: Republican-era readers who are supposed to refrain from excessive yin and qing, the Western-educated Chinese man whose superior Confucian morality cuts him off from homo-social activities in a different cultural setting that he considers immoral, the lonely traveller who is always on the move, and the transnational startuper, surrounded by other "competing" desirabletransnational bodies, who has to strive every day to perfect their image as a work-hard play-hard transnational elite.

In this sense, these caveats and ambivalences are central to the construction of gendered identities in modern China. All four contributions show as much how boundaries are blurred as how they are delineated: muddying the waters between obscene and legitimate sexual representations, between Chinese and Western conceptions of masculinities, between work and play, professional life and intimacy... Attempts at circumscribing boundaries are encapsulated in the person of the security guards themselves: entrusted with separating clearly between "desirable" upper-class patrons and "undesirable" migrant bodies, but ironically, also migrants themselves. Upon those - highly porous - thresholds rest the enforcement of readily legible gendered identities and their legitimising sheen. And still, under the scrutiny of the intersectional microscope, the convoluted relationships between market, state, and self in the regulation of desires reveal the deemed necessity but ultimate futility of clear-cut boundaries.

\section{Acknowledgements}

This special issue originates from an international conference titled "Re-Envisioning Gender in China" held on 14 -16 February 2019 at the Université libre de Bruxelles (Brussels, Belgium). The conference was generously funded by a grant from the F.R.S.-FNRS and the CEFC Hong Kong, and supported by the Faculty of Letters, Translation, and Communication, Philixte, EASt, and Striges of the Universite libre de Bruxelles (ULB, Belgium), the SOAS China Institute, the SOAS Centre for Gender Studies, and the Department of History at King's College London.

The authors are co-founders of the China Academic Network on Gender (CHANGE), a transnational interdisciplinary network for scholars dedicated to researching Gender in China.

I Coraline Jortay recently obtained her PhD from the Université libre de Bruxelles (ULB, Brussels, Belgium). Her research focuses on the literary debates following the "invention" of gendered pronouns in Chinese, and more generally on pronominal re-appropriations in twentieth and twenty-first century Sinophone literature. In the fall of 2020, she will take up a position as a Wiener-Anspach Postdoctoral Fellow at the Oxford China Centre, and a Junior Research Fellow of Wolfson College, University of Oxford. Oxford China Centre, Dickson Poon Building, Canterbury Rd, Oxford OX2 6LU, United Kingdom (coraline.jortay@ulb. ac.be).

I Jennifer Bond is an Assistant Professor in Asian History at University College Dublin. She is currently writing a book that explores the identity negotiations of Chinese women educated at missionary schools in Republican era East China. Jennifer Bond, School of History, University College Dublin, Belferild, Dublin 4, Ireland (jenny.bond@ucd.ie).

\section{Liu Chang is a Lecturer at the Chinese University of Hong Kong} (Shenzhen). Her ongoing book manuscript investigates the changing cultural-political discourses about single womanhood in the first half of twentieth-century China and the everyday lives of actual middleclass single women in urban areas, with a focus on Shanghai. School of Humanities and Social Science, The Chinese University of Hong Kong (Shenzhen), 2001 Longxiang Road, Longgang District, Shenzhen, Guangdong, China, 518172 (liuchang@cuhk.edu.cn). 


\section{References}

ATTANÉ, sabelle. 2012. "Editorial." China Perspectives 4(92): 2-3.

BENNETT, Claire-Louise. 2016. Pond. Dublin:The Stinging Fly.

BROWNELL, Susan, and Jeffrey N. WASSERSTROM. 2002. Chinese Femininities/Chinese Masculinities: A Reader. Berkeley: University of California Press.

BUTLER, Judith. [1990] 1999. Gender Trouble: Feminism and the Subversion of Identity. New York: Routledge.

CRENSHAW, Kimberlé. 1989. "Demarginalizing the Intersection of Race and Sex: A Black Feminist Critique of Antidiscrimination Doctrine, Feminist Theory and Antiracist Politics." University of Chicago Legal Forum: 139-67.

DOOLING, Amy D. 2005. Women's Literary Feminism in TwentiethCentury China. New York: Palgrave Macmillan.
HERSHATTER, Gail. 2007. Women in China's Long Twentieth Century. Berkeley: University of California Press.

HERSHATTER, Gail. 2012. "Disquiet in the House of Gender." The Journal of Asian Studies 71(4): 873-94.

HERSHATTER, Gail. 2019. "Blindspotting, Gender, and China's Revolutions." Keynote address at the Second Conference of the China Academic Network on Gender, "Re-envisioning gender in China," 14-16 February 2019, Université libre de Bruxelles (ULB), Belgium.

hooks, bell. 2003. "The Oppositional Gaze: Black Female Spectators." The Feminism and Visual Cultural Reader: 94-105.

YATES, Robin D.S., and Danni CAI. 2018. "Bibliography of Studies on Women and Gender in China since 2008." Nan Nü 20(1): 3-152. 